Gut, 1982, 23, 415-416

\title{
Splenic function in childhood coeliac disease*
}

\author{
G R CORAZZA†, R LAZZARI, M FRISONI, \\ A COLLINA, and G GASBARRINI
} From the Third Department of Medical Pathology and Paediatrics, Policlinico S. Orsola, Bologna University,
Bologna, Italy

SUMMARY We measured splenic function using a simple, non-isotopic method in childhood coeliac disease. No patients were shown to have hyposplenism. This has important clinical and therapeutic implications.

Hyposplenism is a well-recognised feature of adult coeliac disease ${ }^{12}$ and it has recently been suggested that it is the cause of the autoimmune disorders frequently associated with coeliac disease. ${ }^{3}$ Although the risk of infection connected with splenectomy or impaired splenic function is particularly severe in children, ${ }^{4}$ only scanty and inadequate information on splenic function in childhood coeliac disease is available.

We measured splenic function in coeliac children by a new test, ${ }^{5}$ proved to be useful in adult coeliac patients ${ }^{6}$ and based on the observation of red cell membrane abnormalities under interference-phase microscopy.

\section{Methods}

\section{PATIENTS}

Thirty-seven patients (aged 8 months to 13 years) with flat jejunal mucosa were studied. Ten untreated patients who later showed a clear clinical remission after gluten withdrawal and eight patients with a deterioration of the mucosa during gluten challenge were regarded as active coeliac patients. Ten patients on a gluten free diet who showed a histological improvement at the second biopsy and nine children who had met all the ESPGAN criteria for diagnosis $^{7}$ were regarded as inactive coeliac patients. The controls comprised 19 healthy children and 25 patients with minor gastrointestinal disturbances matched for sex and age with the coeliac patients. Thirteen patients (aged 5 to 15 years) who had undergone an elective splenectomy during the staging procedure of Hodgkin's disease were also studied.

* Presented in part at the XXIII Congress of the Italian Society of Gastroenterology, Bologna, July 1981.

+ Address for correspondence: Dr G R Corazza, III Patologia Medica, Policlinico S. Orsola, Via Massarenti 9, 40100 Bologna, Italy.

Received for publication 19 October 1981
SPLENIC FUNCTION MEASUREMENT

A drop of venous blood was mixed with a buffered glutaraldehyde solution; then 2000 red blood cells were examined blind under interference-phase microscopy. The number of cells showing one or more surface pits (pitted red cells) was expressed as a percentage and considered as a measure of splenic function. 5

\section{STATISTICS}

The percentage of pitted red cells in coeliac children, splenectomised patients, and controls were compared using Wilcoxon's rank sum test.

\section{Results}

No significant difference was found between coeliac patients (mean $0.74 \%$, range $0-2.7 \%$ ) and controls (mean $0.79 \%$, range $0-1.8 \%$ ) or in the coeliac group between active (mean $0.74 \%$, range $0-2.1 \%$ ) and inactive (mean $0.74 \%$, range $0.1-2.7 \%$ ) patients. Values for splenectomised patients (mean $25.25 \%$, range $15-31 \%$ ) were significantly higher than in coeliac patients or controls $(\mathrm{p}<0.001)$ (Figure).

\section{Discussion}

The risk of infection connected with functional or surgical asplenia ${ }^{4}$ and the finding at necropsy of splenic atrophy in two children thought to be coeliacs, ${ }^{89}$ prompted us to evaluate carefully splenic function in childhood coeliac disease. The study of splenic function in coeliac children has been hampered by the lack of a non-radioisotopic method. The percentage of pitted red cells has been shown to correlate with splenic function as measured by heat-damaged red cell clearance,${ }^{6}$ and therefore this method is ideally suited for investi- 
Figure Percentage of pitted red cells in four groups of subjects.

\section{CONTROLS ACTIVE INACTIVE SPLENECTOMY COELIACS COELIACS}

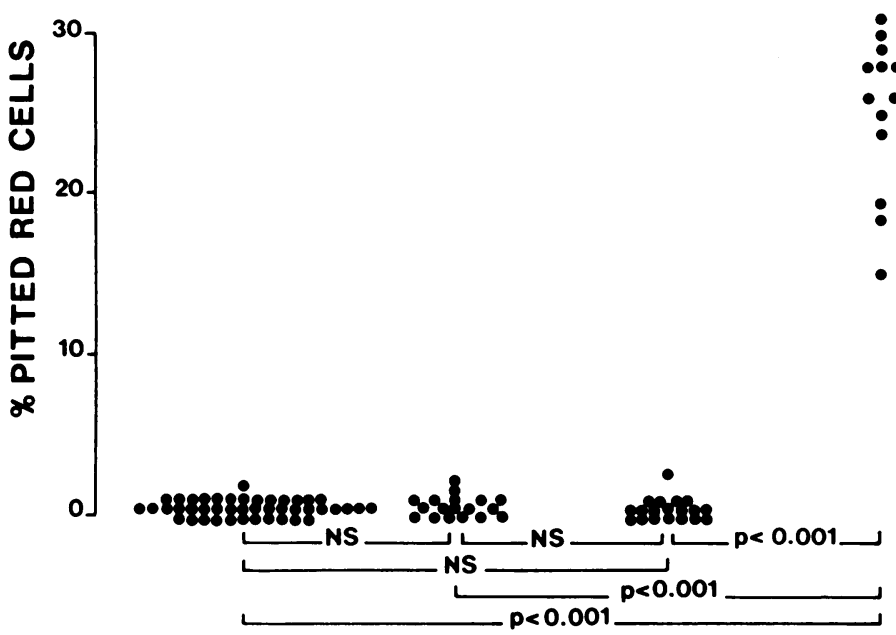

gation of splenic function in children. By counting pitted cells we have shown that splenic function in both active and inactive coeliac children was not depressed when compared with controls and splenectomised patients. These results confirm and extend previous findings by McCarthy et $a^{10}$ who, by counting Howell-Jolly bodies, were not able to show any lymphoreticular dysfunction in 29 young coeliac patients. The incidence of hyposplenism in adult treated coeliacs seems to be related to the duration of exposure to gluten. ${ }^{6}$ Thus it is possible to speculate that the immunological abnormalities of adult coeliac disease have not been present long enough in childhood coeliac disease to produce hyposplenism. Our results therefore suggest that splenic hypofunction is not a complication of childhood coeliac disease and that young coeliacs, even in a poor nutritional state, do not need any particular protection against the risks of hyposplenism.

Counting of pitted red cells is an easily repeatable test of splenic function and we intend to follow up a group of coeliac children in order to gain further information on the timing of the development of hyposplenism and its possible connection with other immunological abnormalities of coeliac disease.

\section{References}

1 Marsh GW, Stewart JS. Splenic function in adult coeliac disease. Br J Haematol 1970; 19: 445-57.

2 Robinson PJ, Bullen AW, Hall R, Brown RC, Baxter $\mathrm{P}$, Losowsky MS. Splenic size and function in adult coeliac disease. Br J Radiol 1980; 53: 532-37.

3 Bullen AW, Hall R, Gowland G, Rajah S, Losowsky MS. Hyposplenism, adult coeliac disease, and autoimmunity. Gut 1981; 22: 28-33.

4 Bullen AW, Losowsky MS. Consequences of impaired splenic function. Clin Sci 1979; 57: 129-37.

5 Pearson HA, Johnston D, Smith KA, Touloukian RJ. The born-again spleen. Return of splenic function after splenectomy for trauma. $N$ Engl J Med 1978; 298: 1389-92.

6 Corazza GR, Bullen AW, Hall R, Robinson PJ, Losowsky MS. Simple method of assessing splenic function in coeliac disease. Clin Sci 1981; 60: 109-13.

7 McNeish AS, Harms HK, Rey J, Shmerling DH, Visakorpi JK, Walker-Smith JA. The diagnosis of coeliac disease. Arch Dis Child 1979; 54: 783-86.

8 Macrae O, Morris N. Metabolism studies in coeliac disease. Arch Dis Child 1931; 6: 75-96.

9 Meyer A. Uber Coeliakie. Z klin Med 1932; 119: $667-86$.

10 McCarthy CF, Fraser ID, Evans KT, Read AE. Lymphoreticular dysfunction in idiopathic steatorrhoea. Gut 1966; 7: 140-8. 